\title{
An Analysis of the Tuna Diplomacy between Pacific Island Countries and EU -Take Kiribati as an example
}

\author{
Fan Xuande ${ }^{1 *}, \mathrm{Gu}$ Yuting $^{2}$ \\ ${ }^{1}$ Liaocheng University \\ ${ }^{2}$ Qinghai Normal University
}

\begin{abstract}
Abundant tuna resources have important economic and political significance for Pacific island countries, and obtaining more benefits from tuna resources is the consistent pursuit of Pacific island countries. This article selects Kiribati as an example, mainly for consideration of its national conditions. Kiribati is a maritime country, it's the world's largest coral atoll, and it is famous for the Phoenix Islands Protected Area (PIPA). Kiribati's water area is larger than land, its citizens mainly rely on fishing for their livelihoods and commercial activities. Kiribati declared its exclusive economic zone (EEZ) in 1978, it currently has 3.55 million square kilometers, which is equivalent to the area of India. Besides, no other resources can make a huge economic contribution to Kiribati. Therefore, obtaining economic and political gains from abundant tuna resources is an urgent need for Kiribati. The EU has a huge tuna consumer market in the world, and there is a huge demand for tuna. The Atlantic fisheries are affected by overfishing, which has led the EU to seek new fisheries around the world. In addition to that, participating in the tuna affairs of Pacific island countries will also have a positive effect on enhancing the EU's influence in the Pacific island countries. The two sides immediately started cooperation on tuna affairs. This article takes Kiribati's tuna diplomacy with the European Union as an example and take the fishery partnership agreement signed by the two sides as the starting point to discuss the cooperation between them in tuna fishery and some frictions in the cooperation. In the end of this article, the authors briefly summarize the way Kiribati can further benefit from tuna resources in the future.
\end{abstract}

\section{Introduction}

The EU has a huge tuna consumer market in the world and has a huge demand for tuna. The Atlantic fisheries are affected by overfishing, which makes the EU seek new fisheries worldwide to meet its huge demand for tuna. Besides, participating in the tuna affairs of the Pacific island countries has a positive effect on enhancing the EU's influence in the Pacific island countries. On the other hand, Pacific island countries are trying to obtain further economic and political benefits from their abundant tuna resources. The two sides immediately started cooperation on tuna affairs.

The EU has signed bilateral tuna agreements with four Pacific island countries, namely Kiribati, Solomon Islands, Micronesia and the Cook Islands. The first fisheries agreement reached between the EU and Kiribati can be traced back to 2003. This is the first bilateral fishery agreement signed by the EU in the Pacific. The EU and the Solomon Islands have signed bilateral fisheries agreements twice, the first in 2006 and the second in 2009, which expired in 2012. The EU and the Federated States of Micronesia concluded the first bilateral fisheries agreement in 2007 and expired in 2016. The EU and the Cook Islands signed a bilateral fisheries agreement for the first time in 2016 and will expire in 2020 .

This article selects Kiribati as an example, mainly for the consideration of Kiribati's economy. ${ }^{1}$ First, Kiribati is one of the least developed countries. The per capita gross national income of developing countries is US\$7064, while Kiribati is only US\$2986. Compared with other Pacific island countries, its economic development level is lower; on the other hand, Kiribati's economic vulnerability index is as high as 73.7 , while the average for developing countries is 34.7. Except for the abundant tuna resources, no other resources can make a huge economic contribution to Kiribati; therefore, the economy and politics are obtained from the abundant tuna resources Obtaining benefits is an urgent need for Kiribati.

\footnotetext{
*Corresponding author: fanxuandelib@outlook.com
} 


\section{The origin of Kiribati's cooperation with the EU}

\subsection{The important position of tuna fishery in Kiribati}

Kiribati is a maritime country, as Claire Anterea, the Convenor of the Climate Action Network in Kiribati, said: "We call the sea in Kiribati our Mother Ocean, We eat fish in the morning for breakfast, we eat fish for lunch and we eat fish at dinner time. And in our day, we get money also from our ocean. Young people, the men go out fishing, and then the women sell the fish along the roads." ${ }^{2}$ Kiribati is the largest coral atoll in the world and is known for the Phoenix Islands Protected Area (PIPA), which was declared the world's largest marine protected area in 2010.It is located in the middle of the Pacific Ocean and consists of 33 islands. The total land area is only $810 \mathrm{~km}^{2}$. The distance between any location on the island and the sea will never exceed 500 meters. It is mainly composed of three island groups: Gilbert Islands in the west, Phoenix Islands in the middle and Line Islands in the east. ${ }^{3}$ Kiribati has a larger water area and has the largest waterland ratio in the world. Its citizens mainly rely on fishing for their livelihoods and commercial activities, and about $80 \%$ of the population make a living on it. In 2015, the export value of fish and fish products was US\$121.4 million, of which tuna was the main export species. Kiribati declared its exclusive economic zone (EEZ) in 1978, it currently has 3.55 million $\mathrm{km}^{2}$, which is equivalent to the area of India. ${ }^{4}$ This vast ocean area has excellent potential for the development of the tuna industry.

After Kiribati's independence, foreign ocean-going fleets are still active in Kiribati waters, and their total fishing fees have increased to one-third or more of the government's annual revenue. The tuna income has replaced the income from the phosphate mining industry as the country's economic pillar. The income from marine tuna fishery is a valuable source of government revenue, providing $60 \%$ of it. At the same time, it also plays an essential role in food security and national employment. The total value of Kiribati's coastal and offshore fisheries is estimated to exceed 110 million Australian dollars per year. Given the importance of these resources, it is crucial to properly maintain and manage these resources in the future. However, it is believed that the income from the entry fee has not kept up with the development of the Western and Central Pacific fisheries. Kiribati's fishing fees peaked in 2001, at about 46 million Australian dollars, and dropped to 25 million Australian dollars in 2005 and 2006. From 2007 to 2009, tuna income gradually climbed to about 30 million Australian dollars, and reached its peak again in 2010, about 41.7 million Australian dollars. However, the value of fish caught in Kiribati waters increased by $130 \%$ during this period. In 2011, the income dropped significantly, reaching 26.9 million Australian dollars, ${ }^{5}$ but this was mainly due to the unfavorable fishing season and the strong La Niña phenomenon, which caused tuna fish stocks to move to the Western Pacific. This phenomenon meant increased revenue for western countries. Nevertheless, it is a loss for the central and eastern countries, such as Kiribati. Kiribati's fisheries sector is divided into two main categories: one is coastal fisheries, also called artisanal fisheries, which are usually self-sufficient and small-scale commercial activities. The other one is the offshore fishery, which is an industrialscale commercial tuna fishery. Purse seine fishery occupies a significant position in Kiribati's tuna fishery, mainly concentrated in the Gilbert and Phoenix Islands. ${ }^{6}$ Kiribati has also approved a large number of foreign longline fishing fleets, which mainly fish for bigeye tuna, yellowfin tuna, albacore tuna and tuna related species. Longline fishing is mainly in the Line Islands. Commercial fishing is concentrated near the capital Tarawa, where the large number of population, the modern economy condition and cold storage facilities provide suitable market conditions. A large amount of tuna is caught in offshore fisheries, but most of the catch is caught by foreign fishing fleets. This is due to Kiribati's limited economic and technological level.

Fishery resources play a vital role in Kiribati's income, food security and employment. However, the management and development of tuna resources are increasingly being challenged by domestic and foreign factors. Although coastal fisheries are currently the primary source of protein for most I-Kiribati, population pressure, overfishing, climate change, and rising global food prices have posed severe challenges to their food security. ${ }^{7}$ Regional and global developments have also exacerbated this challenge, especially in the tuna fisheries, as the PNA (Party of the Nauru Agreement) countries are striving to control their fisheries and processing industries. These internal and external changes indicate that Kiribati needs to implement strict and complete management measures and effectively participate in various treaties and arrangements related to the tuna industry to maximize economic benefits and ensure the sustainable use and conservation of tuna resources.

To adapt to this changing environment, Kiribati must have a clear vision and take comprehensive measures to manage and develop its fisheries. As an island country, it is a vast and complicated task to deal with the current and future challenges of tuna fishery and establish a sound tuna industry, however it is very important for Kiribati to improve its economic strength and political status.

\subsection{EU's demand for tuna resources}

Tuna is the most consumed marine species in Europe, and it is an indispensable part of the diet of millions of Europeans. The import volume of European tuna and tunalike species is significantly higher than its production and export volume. In 2018, Europe imported 1,365,545 tons 
of tuna and exported 311,723 tons. The production of wild and farmed tuna and similar tuna was only 418,155 tons. The self-sufficiency rate of tuna in Europe was 28\% in 2016 and $23 \%$ in 2018 . ${ }^{8}$ The massive demand for tuna makes the EU import tuna from worldwide to meet the demand. The abundant tuna resources in Kiribati's exclusive economic zone will undoubtedly help fill the EU tuna market gap. Besides, with the gradual exhaustion of existing fishery resources in other parts of the world and the continuous expansion of China, India and ASEAN, the demand for fishery resources will continue to increase. A large number of fishery resources in the Pacific will become more and more critical. Therefore, the European Union Paying more attention to the sustainable management of tuna to promote the sustainable development of fishery resources in the Pacific. The EU and Kiribati are cooperating to develop tuna resources in the exclusive economic zone and promote its sustainable development. The EU's participation in Kiribati's tuna fishing can not only increase the supply of the EU's tuna market, but also increase the EU's political influence in the Pacific.

\section{Kiribati and EU tuna cooperation and diplomatic friction}

The cooperation between Kiribati and the EU is mainly manifested in the signing of the three fishery partnership agreements. By comparing the three fishery partnership agreements, we can see that tuna resources have brought more revenue to Kiribati, and the EU has paid more attention to Kiribati's fishery resources. However, cooperation has not been smooth sailing. Due to differences in the interests of the supply and demand parties, development demands, and regulatory capabilities, some friction has also arisen.

\subsection{Signing of Kiribati and EU Fisheries Partnership Agreement}

In order to further develop the tuna resources in its exclusive economic zone and promote its sustainable use, Kiribati signed the Fisheries Partnership Agreement with the European Union in 2003, becoming the first Pacific island country to sign a fisheries agreement with the EU. The two sides subsequently signed new tuna fisheries partnership agreements in 2007 and 2012. The parties seek to benefit from the vast reserves of tuna in Kiribati's exclusive economic zone and introduce responsible fishing practices to ensure the sustainable use of tuna stocks. The agreement includes annual EU financial aid to Kiribati, annual reference tonnage of EU catches, the number of EU fishing vessels entering Kiribati's exclusive economic zone and the cost of fishing licenses. The main contents of the three agreements are as follows:

In the 2003 Tuna Fisheries Partnership Agreement, the EU's financial assistance program for Kiribati was to deliver 546,000 euros to the Kiribati authorities in the first year, which is equivalent to the capture of 8,400 tons of tuna in Kiribati's exclusive economic zone, and then 416,000 euros per year, which is equivalent to catching 6,400 tons of tuna each year. Within the agreement period, the number of EU fishing vessels in the exclusive economic zone is 6 purse seine vessels and 12 longline fishing vessels in the first year. In the following years, there were 4 purse seine fishing vessels and 12 longline fishing vessels. The license fee of the fishing fleet is 21,000 Euros per purse seiner and 4200 Euros per longline. ${ }^{9}$

In the 2007 Tuna Fisheries Partnership Agreement, the EU's financial assistance to Kiribati was 478,400 Euros per year, which is equivalent to the annual catch of 6,400 tons of tuna. Within the term of the agreement, there are 4 purse seine vessels and 12 longline fishing vessels in the exclusive economic zone. The license fee for fishing vessels is 21,000 euros per seine fishing vessel and 4,200 euros per longline fishing vessel. ${ }^{10}$

In the 2012 Tuna Fisheries Partnership Agreement, the EU's financial assistance to Kiribati was 478,400 euros per year, which is equivalent to the annual catch of 15,000 tons of tuna. During the term of the agreement, there are 4 purse seine vessels and 6 longline fishing vessels in the exclusive economic zone. The license fee for fishing vessels is 131,250 euros per seine fishing vessel and 15,000 euros per longline fishing vessel. ${ }^{11}$

Compared with the fishery agreement in 2007 and 2003, the EU's economic assistance to Kiribati has not changed significantly. The reference tonnage of tuna caught each year is the same except that the first year; The number of fishing vessels entering the exclusive economic zone is different in the first year, it's the same in subsequent years; The fishing vessel license fees are the same.

In the 2012 fisheries agreement, the number of permitted fishing fleets decreased, and the reference tonnage of catches rose sharply. The EU's financial assistance to Kiribati also rose to a great extent, rising to 1325,000 euros per year, that is it has almost tripled compared to 2007.

There are many reasons for the sharp increase in Kiribati's economic assistance, not only from the increase in the value of tuna, but also from the introduction of VDS (Vessel Day Program). VDS is a mechanism held and promoted by the Pacific Ocean. Since its introduction, fishing fees have risen sharply, which has improved the Pacific Ocean's negotiation status. ${ }^{12}$ In addition to substantial financial returns, the VDS eventually gave Pacific countries control of their resources, which strengthened the ability to negotiate. In addition, the EU is paying more and more attention to Kiribati's fishery resources to prevent IUU (illegal, unreported and unregulated) fishing. IUU fishing is not only one of the greatest threats to the marine ecosystem, but also has a huge destructive effect on national construction, because 
it has the potential to undermine national and regional efforts to manage fisheries in a sustainable manner and to protect marine biodiversity. IUU fishing uses corrupt administration and weak management systems, especially the lack of effective monitoring, control and supervision capabilities and resources in developing countries, which will exacerbate poverty and increase food insecurity. Therefore, the EU has increased its assistance to Kiribati to promote Kiribati's fishery resources to bring sustainable benefits to both sides.

Table 1. Three Fisheries Partnership Agreements

\begin{tabular}{|c|c|c|c|}
\hline Agreement initial time & 2003 & 2007 & 2012 \\
\hline The nature of FPA & $\begin{array}{c}\text { Tuna Fisheries Partnership } \\
\text { Agreement }\end{array}$ & $\begin{array}{c}\text { Tuna Fisheries Partnership } \\
\text { Agreement }\end{array}$ & $\begin{array}{c}\text { Tuna Fisheries Partnership } \\
\text { Agreement }\end{array}$ \\
\hline Financial contribution & $\begin{array}{c}\text { The first year is set at 546,000 } \\
\text { euros, followed by 416,000 euros } \\
\text { / year. }\end{array}$ & 478,400 euros / year. & $\begin{array}{c}\text { 1325,000 euros / year, of which } \\
\text { been designated to support the } \\
\text { Kiribati sector's fisheries } \\
\text { policy. }\end{array}$ \\
\hline Reference tonnage & $\begin{array}{c}8400 \text { tons / year in the first year, } \\
6400 \text { tons/year thereafter }\end{array}$ & the first year \\
Number of fishing boats & $\begin{array}{c}\text { Seine fishing boats: } 6 \\
\text { Longline fishing boats: } 12 \\
\text { Subsequent years } \\
\text { Seine fishing boats: } 4, \\
\text { Longline fishing boats: } 12\end{array}$ & $\begin{array}{c}\text { Seine fishing boats: } 4, \\
\text { Longline fishing boats: } 12\end{array}$ & $\begin{array}{c}\text { Seine fishing vessels: } 4 \\
\text { Longline fishing boats: } 6\end{array}$ \\
\hline License fee & $\begin{array}{c}\text { Seine fishing boat: } 21000 \text { euros } \\
\text { Longline fishing boat: } 4200 \\
\text { euros }\end{array}$ & $\begin{array}{c}\text { Seine fishing boat: } 21,000 \\
\text { euros } \\
\text { Longline fishing boat: } 4200 \\
\text { euros }\end{array}$ & $\begin{array}{c}\text { Longline fishing boat: } 15,000 \\
\text { euros }\end{array}$ \\
\hline
\end{tabular}

The third fisheries agreement expired in 2015. The two sides signed a fisheries partnership agreement to conduct extensive cooperation in tuna fisheries. The EU was able to enter Kiribati's exclusive economic zone to fish for tuna to meet its huge demand. Kiribati has obtained generous economic assistance from it. In addition to gaining economic benefits, Kiribati has also improved its international influence by establishmenting of a cooperative relationship with the European Union.

\subsection{Frictions in cooperation between Kiribati and EU in tuna fisheries}

Kiribati and the European Union will inevitably have frictions in the tuna fishery cooperation. While developing tuna resources with Kiribati, the European Union attaches great importance to the sustainability of tuna resources and strives to prevent and stop IUU fishing. Some Pacific island countries are also dissatisfied with Kiribati's issuance of these ships' licenses, believing that before the whole Pacific island countries negotiate with the EU, issuing licenses to EU ships is not conducive to the development of Pacific island countries' regionalism. There is a gap in the development level among Pacific island countries, and Kiribati is still among the least developed countries, and economic development is an urgent need. Due to the huge gap in economic strength, it is inevitable that the parties involved in the cooperation will have discord.

The diplomatic friction between Kiribati and the EU is reflected in the 2016 EU's identification of Kiribati as a non-cooperative third country (non-EU member state). The European Commission believes that there are sufficient signs that Kiribati is unable to provide information on the characteristics of highly migratory species captured by its fishing fleet or on the fishing products unloaded or transshipped at its port and the trade flows of these products. In fact, Kiribati's control of the port seems to be a series of document checks (mainly including permit status, tracking of ship monitoring systems, observer reports and FFA good reputation records $)^{13}$ before fishing vessels are allowed to enter the port. Kiribati admitted that there is no traceability system for fishery products caught by fishing vessels flying its flag or by third-country fishing vessels that fish and transship in its waters and ports. Once these fish are landed or transshipped at the port of Kiribati, there is no way to track these products in subsequent steps in the supply chain. Kiribati's weak control over unloading and transshipment at its port hinders the traceability of fishery products. Therefore, the transparency of its market cannot be guaranteed, and it cannot be ensured that the fishery product trade in the country does not come from IUU fishing.

The European Union believes that Kiribati is unwilling to cooperate with the European Commission to increase 
the transparency of the vessel day plan for the management of the seine fishery in the Western and Central Pacific. The EU has improved Kiribati's transparency by sending three letters to the Kiribati authorities on November 18, 2014, December 19, 2014, and April 27, 2015. Although the Kiribati authorities expressed their willingness to share VDS information during the visit in November 2015, none of the three requests were answered before the committee visited Kiribati. In addition, Kiribati's Fisheries Law does not seem to involve recidivism. Dealing with repeated crimes is also critical to ensuring a deterrent sanction system. Failure to clearly define repeated crimes as higher penalties undermines the deterrence of Kiribati's sanctions regime. The ever-increasing sanctions will not offset the proceeds of repeated illegal activities, and therefore cannot prevent potential criminals from continuing IUU activities. The European Union issued a yellow card to Kiribati (the EU issued a formal warning to the third country identified as IUU fishing for improvement), and Kiribati believed that the EU sought to strengthen its protection against Kiribati tuna during the negotiation of the partnership agreement and the process of controlling IUU fishing. The control of fisheries attempts to have a say in the management of Kiribati's tuna resources.

There are many reasons for the friction between the two sides of tuna diplomacy. The first one is the different economic development status of the two sides. Kiribati is trying to get more enormous benefits from a single natural resource in order to change the current economic situation. This is a relatively complicated process. This article believes that in the 2003 and 2007 fisheries agreements, the EU's economic assistance to Kiribati is not sufficient, which is related to the weak domestic economic development of Kiribati. The main reasons for this situation are as follows:

First of all, Kiribati has a minimal land area. Most of the islands are located in the equatorial marine climate zone. This is an area with continuous drought, plus alkaline soil and no surface water. The only source of water is groundwater, and rainwater penetrates through porous topsoil to supplement groundwater. Therefore, the local conditions for agricultural development are very limited. In addition to the abundant fish and marine resources in its exclusive economic zone, Kiribati's mineral resources are also very limited, which means that Kiribati mainly depends on their marine resources for income and occupies a considerable proportion of the local people's diet.

Secondly, Kiribati's fishery processing industry is restricted by many factors, of which weak cargo capacity is one of the limiting factors. Kiribati is far from major international transportation routes and consumer markets, the long distance from major trading ports, and the very small volume of goods entering and leaving Kiribati ports, all of which have pushed up freight prices. The port facilities of Betio in Tarawa are not broad enough or deep enough to accommodate large ships. Large cargo ships can only be unloaded in shallow coastal waters, and the cargo is unloaded from the ship to the barge, and then transported by the barge to the dock for unloading. In addition, the wharf built in Kiritimati was built for satellite projects in Japan and the United States. It is suitable for large ships carrying rocket components, but the wharf is too high for fishing boats. Furthermore, this pier does not have enough place to shelter from bad weather. ${ }^{14}$ Fishery processing companies are also facing many problems. Atolls rely on rainwater collected from the roof or groundwater collected by wells or pumps. The supply of fresh water is insufficient. The overcrowded Tarawa affects the quality of groundwater and there is not enough fresh water for large factories. So it needs a desalination plant. But the problem with the desalination plant is that it consumes much fuel, and Kiribati's fuel relies on external transportation and is expensive. The local power supply is also unreliable, with power outages for several hours every few weeks.

In addition to that, the development of infrastructure is a major concern of Kiribati. Due to the small size and the pressure of the population, the development of any infrastructure requires careful planning and consideration of environmental and socio-economic impacts. Coastbased processing and development costs are too high, almost Not competitive. In addition, overpopulation's environmental and socio-economic problems have increased sharply, at the same time there is a lack of sufficient high-tech talents to support the development of the government and the fishery industry. The aspects mentioned above have restricted Kiribati's economic development to varying degrees, are not conducive to the development of the local tuna fishery processing industry, and have a specific impact on the EU's tuna diplomatic mediation.

\section{Prospects for the development of Kiribati tuna fishery}

Although Kiribati and the European Union have some frictions in tuna fishery cooperation, the cooperation between the two sides has also deepened. On June 16, 2017, the European Commission implemented the $2017 / 1089$ decision and included Kiribati in the list of countries whose fishery food products meet the EU market food safety requirements. Kiribati confirmed this and became the fourth Pacific country, after Fiji, the Solomon Islands and Papua New Guinea, to enter the European Union's tuna market. ${ }^{15}$ The EU is one of the most stringent tuna consumer markets in the world. The entry process is quite complicated, it needs to prove that its seafood export control structure is same as the EU. It took a long time and energy for Kiribati to get to this step. This is an impressive milestone for Kiribati. In order to further profit from tuna resources, political and economic efforts are both needed. 


\subsection{Reasonable use of "Pacific leverage" for profit}

Kiribati's diplomacy with the EU is at a relatively disadvantaged position in the negotiations because it only possesses a single tuna resource. To benefit from tuna resources, it is indispensable to take advantage of the various forces in the Pacific to increase the bargaining chip in tuna diplomacy. In addition, the micro-states of the Pacific island countries rely on external aid, which provides opportunities for cost-effective diplomatic initiatives for competing regimes, at the same time, the Pacific island countries also benefit from their political attention and economic assistance.

During the diplomatic tension between the Soviet Union and the United States in the 1980s, it provided the Pacific with external leverage. Kiribati seized the opportunity and signed a fisheries agreement with the Soviet Union in 1985. Vanuatu and other Pacific nations expressed great interest in it. The contact between the Pacific island countries and the Soviet Union prompted the United States to negotiate an agreement with it, and to a certain extent made concessions to the requirements of the Pacific island countries. The United States cannot ignore the problems of security and power balance brought about by the existence of the Soviet Union. This has created "the lever of the Pacific," which has significantly increased the the Pacific island countries' bargaining chips. ${ }^{16}$ The Pacific island countries are well aware of the enormous power and influence of the Soviet Union's intervention in the United States. During the tensest period of diplomatic relations with the United States, Solomon Islands bluntly expressed to the United States that they would directly contact the Soviet Union. Facts have proved that Pacific island countries using the United States and the Soviet Union's strategic interests can provide effective leverage for the Pacific region, it not only forcing the United States to make concessions, but also enhancing the strength of the Pacific region. The existence of multiple forces in the Pacific region provides Kiribati with a relatively favorable diplomatic environment. The rational use of the "Pacific lever" will significantly help it benefit from tuna resources.

In addition to the overlap and dominance of Western influence in this region, Asian countries are also trying to increase their influence in this region. Taiwan and China pay special attention to the region and use it as a stage for diplomatic competition. Beijing replaced Taipei and gained international recognition in the United Nations in 1971. The Taipei authorities tried their best to offset Beijing's diplomatic victory by seeking new friends in the emerging independent third world countries. Both Taipei and Beijing turned their attention to the South Pacific, where the decolonization process provided fertile ground for diplomatic initiatives by both sides, and these diplomatic initiatives were embraced by island leaders eager to assert their independence. ${ }^{17}$ The pro-Beijing Kiribati President Tanetti Maamau, who was first elected in 2016 and successfully re-elected in June 2020, suddenly decided to choose Beijing to establish diplomatic relations in September 2019 interrupting the diplomatic relations with Taipei that had been maintained for many years. Beijing has used monetary diplomacy and financial support in this area, and it has gained recognition from countries such as Kiribati. Kiribati also wanders among several opposing regimes to gain more profit.

Compared with other deep-sea fishing countries, the European Union is not a major participant in the Pacific island countries. However, it has the world's largest consumer market for fish and aquaculture processed products, and it is also the world's largest producer of canned tuna. Tuna accounts for nearly $60 \%$ of the EU's total canned fish production. At present, its domestic fleet can only meet $50 \%$ of the EU's demand for fish. According to the reformed "Common Fishery Policy", the EU's fisheries will be reduced by $45 \%$. This indicates that the supply of fish caught in EU waters is in short supply for the EU and may increase in the next few years, that is to say is the Pacific region may become more critical to EU supplies. In addition to that, the EU attaches particular importance to the sustainable development of fisheries, making it easier to reach consensus with Pacific island countries trying to promote the sustainable development of fisheries.

Plus, promoting the integration of Pacific island countries plays a vital role in improving Kiribati's voice and economic development. Kiribati maintains strong regional ties in the Pacific. It is a full member of the Pacific Islands Forum, the South Pacific Applied Geosciences Committee, the South Pacific Tourism Organization, the Pacific Regional Environmental Program and the Pacific Community Secretariat. Also, Kiribati is one of the eight signatories to the Nauru Agreement. The Nauru Agreement involves the cooperative management of fisheries of common interest. The agreement collectively controls $25 \%$ to $30 \%$ of the world's tuna supply and $60 \%$ of the tuna supply in the Midwest Pacific. The development of regionalism will greatly help Kiribati's tuna diplomacy. Regional economic integration and sustainable development, as well as the fair distribution of benefits and costs, will promote the Pacific island countries' prosperity. Besides, lowering material and technical market barriers to enable the free flow of people and goods within and between countries is a necessary measure for Kiribati and other Pacific island countries to benefit from tuna resources. However, this will be a long process.

\subsection{Further improve the domestic tuna industry}

Kiribati attaches great importance to the development of the domestic tuna industry, which is fully demonstrated in the kv20(Kiribati 20 year vision development plan). KV20 is Kiribati's long-term development blueprint for 20162036. This development plan aims to transform Kiribati into a more vibrant, healthier and more peaceful country. This is also Kiribati's first long-term national development plan. The plan puts a special emphasis on maximizing 
profits through sustainable fisheries and marine development. Fishery is one of the priority parts of KV20 to stimulate economic growth and development. The plan's goal is to increase revenue from fisheries and marine resources from AUD 154 million to AUD 227 million by 2019 , and to AUD 1.2 billion by $2036 .{ }^{18}$ To further get rid of the passive status of a single resource holder in the tuna diplomacy process and obtain more excellent benefits from tuna resources, Kiribati must gradually improve its tuna industry, it needs to make improvements in the following aspects:

First, development of transshipment centers is a necessary measure. Kiribati is located in the middle of the Pacific Ocean, with a superior geographical location and outside the tropical cyclone belt, so it is very suitable for developing a transshipment center. The transshipment center will develop the terminal capacity provide supplies, services and repairs to ships. If the facilities are improved, Kiribati may require the ocean fishing fleet to unload part of the catch to local plant for processing. A better port will reduce the cost of goods, create more economic opportunities, and generate many beneficial spin-offs. Well-developed port facilities bring scale economies in freight transport, which means cheaper food and fuel imports.

The second is to develop the local fishery industry. Kiribati's 2015 Census Report shows that for families engaged in fishing, $75 \%$ is used for household consumption, $19 \%$ is used for consumption and sale, and only $4 \%$ is used for sale only. Local fishermen engaged in small-scale fishing have developed fishing skills, but did not develop commercial skills. Operating ships as a business will be a brand new way of operating. I-Kiribati who work in the ocean-going fleet are familiar with the operation of large ships, but have no chance to master more knowledge of tuna business operations, because this type of business is mainly taken in the office on the shore.

I-Kiribati are excellent fishermen, but they lack access to business community. The successful self-employed fishermen in Tarawa did not operate the fishing boat as a business, but as a part of the family's economic production. When they have enough funds to buy fuel, equipment and ice, they will go fishing, sell the surplus and use the profit to buy consumables. They do not record the relationship between the cost and profit of the fishing activity. The Ministry of Fisheries of Kiribati hoped that small-scale fishermen would expand their scale, purchase larger fishing vessels and conduct commercial operations. The Kiribati Development Bank is willing to provide loans to local fishermen, but the Ministry of Fisheries cannot encourage any local fishermen to take practical actions. The Permanent Secretary of the Fisheries Bureau David Yeeting believes that this may be because local fishermen are uneasy about taking on loan risks. Therefore, smallscale fishermen and crew members working on large fishing vessels lack commercial experience. The government will continue to implement policy measures to support private sector participation in local fisheries, create a favorable investment environment, and encourage local fishermen to transform from family fishery to commercial fishery

However, Kiribati also faces many economic obstacles in developing its local fishery industry. First of all, the cost of large fishing vessels is high. The cost of a new purse seine may be as high as US\$12-15 million, and the price of a second-hand purse seine is between US\$6-9 million. The cost of long-line fishing boats is relatively low, but generally more than US\$1 million. In addition to the high cost of ships, fuel, labor, maintenance and licensing costs are very expensive too. The essential operating cost of a large American purse seine may be as high as US $\$ 8,000$ 10,000 per day. ${ }^{19}$ Secondly, another obstacle to the development of Kiribati's fishing industry is ensuring access to the exclusive economic zones of neighboring countries. The highly migratory nature of tuna requires cross-border fishing, but the entry fee determined by the ocean fishing countries is too expensive for the Pacific island countries with lower budgets, the fishing fee also eliminates the advantage of these island countries in the tuna industry that they are close to and free to use tuna resources. Without privileges to visit such island countries such as Kiribati, there is almost no competitiveness. Besides, Kiribati has fewer choices in the tuna industry chain. The tuna industry chain mainly includes raw material harvesting, transfer, processing, and distribution and sales. Kiribati does not have many choices in the way to enter the industry. The raw material link of the commodity chain has limited benefits in the global tuna industry, it is challenging to participate in the more profitable distribution and retail links of the tuna business. ${ }^{20}$

\section{5 conclusion}

This article takes a brief introduction to the background of Kiribati and the EU's cooperation in tuna fishery as a starting point, and briefly explains the frictions and new progress made in the cooperation between the two sides. This article believes that Kiribati's limited level of development of the domestic fishery industry is not conducive to its gaining greater benefits in its early diplomacy with the EU on tuna fisheries. For Kiribati to obtain greater benefits from tuna resources, on the one hand, it needs to make rational use of all forces in its region and actively participate in the regional integration process; on the other hand, it also needs to further strengthen the construction of its fishery industry to get rid of tuna. Relatively disadvantaged position in the industry. As a regional organization with wide-ranging influence in the world, the European Union has a huge tuna consumption market and advanced tuna fishing equipment. It also attaches importance to the sustainable use of tuna resources. It will become an important partner in Kiribati's tuna affairs and play an increasingly important role in the development and utilization of resources. 


\section{Reference}

1. Least Developed Country Category: Kiribati Profile, last modified 2018, https://www.un.org/development/desa/dpad/leastdeveloped-country-category-kiribati.html.

2. Pacific Islands: The Ocean is Our Mother, Aug 29.2012,

https://www.worldbank.org/en/news/feature/2012/08 /29/pacific-islands-the-ocean-is-our-mother

3. Ministry of Fisheries and Marine Resources Development Government of Kiribati, "Kiribati National Fisheries Policy 2013-2025”,2013.

4. FAO Fisheries and Aquaculture Department, "Fishery and Aquaculture Country Profiles," Kiribati,2017, http://www.fao.org/fishery/facp/KIR/en.

5. Food and Agriculture Organization," Fishery and Aquaculture Country Profiles The Republic of Kiribati," Jun 26 ,2018, http://www.fao.org/fishery/facp/KIR/en.

6. European Commision, "EU Relations with The Pacific Islands - A Strategy for A Strengthened Partnership," Official Journal of the European Union, May.29,2006.

7. European Commision,"Agreement between the European Community and the Republic of Kiribati on fishing within the Kiribati fishing zone," Official Journal of the European Union, May.22,2003.

8. European Commision,"Fisheries Partnership Agreement between the European Community, on the one hand, and the Republic of Kiribati, on the other," Official Journal of the European Union, Aug.7,2007.

9. European Commision,"Fisheries Partnership Agreement between the European Community, on the one hand, and the Republic of Kiribati, on the other," Official Journal of the European Union,Oct.30,2012.

10. Greg Fry and Sandra Tarte, "The New Pacific Diplomacy," Canberra: The Australian National University,2015.

11. European Commision," commision decision of 21 April 2016 on notifying a third country of the possibility of being identified as a non-cooperating third country in fighting illegal, unreported and unregulated fishing," Official Journal of the European Union, Apr.21,2016.

12. Kate Barclay and Ian Cartwright," Capturing Wealth from Tuna Case Studies from the Pacific," Canberrain: The Australian National University,2008.

13. European Commision," Commision Implementing Decision (EU) 2017/1089," Official Journal of the European Union, Jun.16,2016.

14. Thomas V. Biddick,"Rivalry in the South Pacific: The PRC and Taiwan," California: University of California, 1989.

15. National Economic Planning Office," KIRIBATI 20YEAR VISION 2016-2036,",2016.

16. Rachel A. Schurman,"Tuna Dreams: Resource
Nationalism and the Pacific Islands' Tuna Industry," Development and Change, vol. 29, no. 1,2002. 